\title{
ФУНКЦІОНУВАННЯ РОЗМОВНОЇ ДІССЛІВНОЇ ЛЕКСИКИ В МОВІ УКРАЇНСЬКОЇ ПЕРІОДИКИ ПОЧАТКУ ХХІ СТОЛІТТЯ
}

\author{
ТЕТЯНА ПАНЧЕНКО \\ ДВНЗ „Переяслав-Хмельницький Державний педагогічний університет \\ імені Григорія Сковороди", Переяслав-Хмельницький - Україна \\ FUNKCJONOWANIE POTOCZNEJ LEKSYKI CZASOWNIKOWEJ \\ W JEZZYKU UKRAIŃSKICH PERIODYKÓW POCZĄTKU XXI WIEKU \\ TETIANA PANCZENKO \\ Państwowa Szkoła Wyższa „Perejaslaw Chmielnicki Państwowy Uniwersytet \\ Pedagogiczny im. Hryhorija Skoworody", Perejaslaw Chmielnicki — Ukraina
}

STRESZCZENIE. W artykule rozpatrzono funkcjonowanie potocznych czasowników różnych grup leksykalno-semantycznych w ukraińskich tekstach publicystycznych początku XXI stulecia, w szczególności przeanalizowano czasowniki mowy. Zaprezentowano leksykę przeważnie z negatywną waloryzacją w tekstach różnych grup tematycznych: charakterystyka władzy, wyborów, stosunków ukraińsko-rosyjskich i działań wojskowych na Wschodzie Ukrainy. Wyznaczono czynniki pozajęzykowe, które wpływają na język publicystyki, a także określono stylistyczną rolę czasowników mowy.

\section{THE FUNCTIONING OF VERBAL CONVERSATIONAL VOCABULARY IN THE UKRAINIAN LANGUAGE PERIODICALS OF THE EARLY XXI ${ }^{\mathrm{ST}}$ CENTURY}

\section{TETYANA PANCHENKO}

State Higher Educational Institution "Hryhoriy Skovoroda Pereyaslav-Khmelnytsky State Pedagogical University", Pereyaslav-Khmelnytsky — Ukraine

ABSTRACT. The article has been devoted to the functioning of colloquial verbs of different lexical-semantic groups in the Ukrainian publicist texts of the early twenty-first century, in particular, the verbs of speech have been analyzed. The characterized lexicon is used mainly with the negative evaluative meaning in the texts of various thematic groups: the characteristics of the authorites, elections, Ukrainian-Russian relations and military actions in Eastern Ukraine. The linguistic factors that affect the language of journalism have been defined; also the stylistic role of the verbs of speech has been stressed upon.

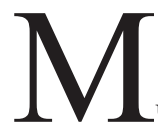
іж функціональними стилями української мови постійно відбувається взаємодія: лексичні одиниці, притаманні одному стилю, можна побачити в іншому, тому поділ лексики ,за належністю до окремих функціональних стилів не можна вважати абсолютним, раз і назавжди даним"1. Найвиразніше стильове взаємопроникнення спостерігаємо в публіцистиці.

У текстах вітчизняних 3МІ журналісти активно використовують і суспільнополітичні терміни, і розмовно-знижену лексику, оскільки їх об'єднує спільна функція - щонайвиразніше донести до читача потрібну думку. На початку XXI ст. спостерігаємо активне проникнення в українську періодику розмовної лексики, зокрема дієслів. Стилістично знижені елементи - це один із найбільш

${ }^{1}$ Б. О. Ко в ален ко, Стилістично знижена лексика в мові сучасної української публіичстики, Автореф. дис. канд. філол. наук, Київ 2003, с.1. 
ефективних засобів досягнення експресивності в публіцистиці, оскільки, завдяки високому енергетичному потенціалу, вони створюють у текстах ЗМІ ефект невимушеної та жвавої розповіді автора.

Актуальність дослідження вбачаємо в тому, що нині активізовано проникнення дієслів розмовного стилю в мову українських газет і журналів, однак це питання $є$ недостатньо вивченим, а в житті суспільства простежуємо зміни, які вносять певні корективи і в розвиток мови.

Мета цієї наукової студії полягає в дослідженні особливостей використання в мові вітчизняної періодики розмовних дієслів різних лексико-семантичних груп, завдання - виявити специфіку використання дієслів розмовного стилю та визначити їхню стильову роль.

Питанням функціонування розмовної лексики в текстах ЗМІ приділяють увагу насамперед такі вчені, як Б. Коваленко, Л. Коробчинська, М. Навальна, О. Сербенська, О. Стишов та інші. Функціонування слів, що належать до лексико-семантичного класу дієслів, їхнє стилістичне навантаження вивчають С. Дишлева, І. Кульчицький, М. Лукач, Ю. Якункіна та ін..

Розмовна лексика — важливий компонент публіцистики. Вона виконує не лише оцінну та експресивну функції, але й сприяє реалізації принципу діалогічного мовлення, є засобом привернення уваги читача, адже, потрапляючи в текст газетної мови, зокрема в оточення суспільно-політичної лексики, вона виразно виділяється на загальному тлі ${ }^{2}$, „Для лексики початку XXI ст. характерні відповідні семантичні та лексичні явища, що зумовлені екстралінгвальними чинниками, які можна пояснити, зокрема, спрощенням і лібералізацією мовних смаків та зняттям цензури і ,заштампованості" мови"з.

„Дієслово завжди називає процес, дію або процесуальний стан і таким чином є основною одиницею мови, що представляє дійсність як рух і за допомогою своїх граматичних категорій відносить цю дійсність до часу — реального або гіпотетичного, а також до суб'єкта або об'єкта дії'4. Існує кілька класифікацій дієслів за лексико-семантичними групами. Так, І. Вихованець поділяє предикати на: 1) предикати дії; 2) предикати стану; 3) предикати якості; 4) локативні предикати 5 .

О. Леута розподілив лексико-семантичні групи дієслів на основі логікограматичного підходу, виокремивши дієслова дії, руху, стану, процесуальні, соціальних та ментальних дій, релятивні (відношення), місцеперебування, буття, характеризації, екзистенційні, володіння ${ }^{6}$.

Авторка цієї розвідки послуговується класифікацією С. Дишлевої, яка, як видається, пропонує найповнішу класифікацію, виокремлюючи 12 лексикограматичних дієслівних груп: 1) дії; 2) руху та переміщення; 3) релятивної семантики; 4) стану і процесу; 5) ментальних і соціальних дій суб'єкта (мовлення, мислення, пізнання і т. д.); 6) звучання та звуконаслідування; 7) буття; 8) на позначення процесів виникнення, появи, настання; 9) характеризації; 10) просторової локалізації; 11) модальні; 12) фазові.

${ }^{2}$ Б. О. Ков аленко, Стилістично знижена лексика..., с. 11.

${ }^{3}$ Там само, с. 5 .

${ }^{4}$ I. М. Кульчицький, М. О Лукач, Огляд підходів до семантичної класифiкаџіï дієслівної лексики, [в:] Наукові записки. Серія „Філологічна”, Національний університет „Львівська політехніка", вип. 14, Львів 2013, с. 112.

${ }^{5}$ I. Р. В ихов ванець, Нариси з функиіонального синтаксису українськоїмови, Київ 1992, с. 93-111.

${ }^{6}$ О. І. Леута, Дієслівні речення в украйнській літературній мові: структура, семанти$\kappa a$, моделі, Автореф. дис. докт. філол. наук, Київ 2009, с 9.

7 C. М. Дишлева, Адвербіальна дистрибуціія лексико-семантичних груп украӥнських дієслів, Автореф. дис. канд. філол. наук, Київ 2008, с 8. 
Досліджуючи тексти вітчизняної періодики, спостерігаємо використання стилістично-знижених дієслів різних лексико-граматичних груп. Найпоширенішими є дієслова мовлення. „Більша частина дієслів мовлення - це назви мовленнєвих актів, зокрема дієслова, що містять семи цілеспрямованої діяльності (шепотіти, проговоритися), та дієслова на позначення обміну мовленнєвим актом (бесідувати, тлумачити)"8. Ці дієслова „відображають не тільки нейтральний процес мовленнєвої діяльності, але й за допомогою додаткових експресивно-оцінних значень дають характеристику мовцеві"9. Лексеми цієї групи мовці вживають не лише під час висловлення власної думки, а й у процесі передачі прямої мови. Серед них виділимо слово втокмачити: “розм., роз'яснюючи або неодноразово повторюючи, домагатися правильного розуміння чи засвоєння чого-небудь" 10 . Його знаходимо в текстах суспільнополітичної тематики, яка, зокрема, стосується відносин що складаються між Україною та Росією, порівн.: Тиснуть праві радикали. Вимагають - жодного слова російською мовою. Складно втокмачити, щзо Росія і російська мова - piзні речі („Країна”, 3.02.2015). Також виділяємо лексему — горлати: “розм., голосно говорити, кричати або співати на все горло"11, порівн.: Моя сусідка була з тих, хто оте "Ра-а-сі-ія" навесні горлала не тільки на мітингах, а й навіть вдома біля телевізора („Україна молода”, 20.11.2014 — далі УМ). Якщо в першому випадку дієслово виконує функцію емоційного підсилення думки, то в другому показує відверту зневагу автора до дій певної категорії людей.

Характеризуючи українсько-російські відносини, журналісти активно послуговуються лексемою торочити: “розм. говорити одне й те саме, повторювати щось кілька або багато разів" "12, порівн.: А куди подінуться ті мешканиі Маріуполя, Слов'янська, Донеиька, Сніжного, Краматорська, Дебальцевого, Волновахи та інших наших міст і сіл, ті, щуо, ніби дресировані папуги, не перестають торочити як не про райське життя “від ДНР-ЛНР” (із циим трохи стихло), то про “київську хунту”... (,Український тиждень”, 7.02.2015); У Мінську підписані два документи, результат - ніякий. Ми розпачливо апелюємо до вересневої лінії розмежування. А вона просувається на захід, фактичний стан змінюеться, ми ж продовжуємо торочити про старе („Газета по-українськи”, 24.03.2015); Росія не зважає на підписані у Мінську папіризі і продовжує наступати, а розумники, у тому числі в Києві, продовжують торочити якусь маячню про мир („День”, 20.03.2015 - далі Д.). Дієслово розмовного стилю торочити виконує в тексті експресивну функцію, підсилюючи думку авторів про те, що вони не підтримують ні розмов мешканців Донецької та Луганської областей щодо доцільності ДНР та ЛНР, ні дій влади щодо Мінських угод, і натякають: чиновники лише говорять, а нічого конкретного не роблять.

Активне вживання розмовних дієслів мовлення спостерігаємо в публікаціях, де подано характеристику влади. Одне з активно вживаних подібних дієслів - шушукатися: “розм., говорити одне з одним пошепки переважно таємно від інших // пошепки розпускати поговір, плітки"13, порівн.: Кілька днів усі шу-

${ }^{8}$ Ю.О.Я Я ункіна, Класифікаиійні ознаки дієслів мовлення в системі дієслівної лексики сучасної украӥнської літературної мови, [в:] „Наукові записки НДУ ім. М. Гоголя. Філологічні науки" 2013, кн. 2, с. 258.

${ }^{9}$ М. I. На вальн а , Нові явища та процеси дієслів соціально-економічної сфери в украӥнській мові, Переяслав-Хмельницький 2014, с. 105.

${ }^{10}$ Словник украӥнської мови, в 11 томах, редкол. І. К. Бі л оді д (гол. ред.), Київ 1970, т. 1, с. 774.

11 Там само, 1971, т. 2, с. 132.

12 Там само, 1979, т. 10, с. 208.

13 Там само, 1980 , т. 11 , с. 569. 
шукалися, мовляв, у нас Янукович у Балаклаві ховається („Тиждень”, 4.12.2015 — далі Т.).

До цієї ж групи дієслів відносимо й лексему просторікувати: “розм., багато, часто беззмістовно говорити"14, порівн.: А адвокати Мельника тим часом уже просторікують $i$ про ймовірну політичну кар'єру свого клієнта (УМ, 20.11.2014); Знову просторікують про ринок землі. Кажуть: запрацює він, і враз Маруся з Іваном стануть багатіями. ... Тематичними дискусіями влада промаиує пульс глибинки: клюне чи ні? А щзо робити із тими впалими на голову доларами потенційним об'єктам злодїв $і$ гадалок? (,Дзеркало тижня", 29.05.-5.06.2015 — далі ДТ). Лексеми репрезентують негативну, несхвальну характеристику людей.

Поширеними в текстах, де, зокрема, описується й виборчий процес та характеризуються його учасники, є лексема балакати: “розм. говорити, казати”, порівн.: Тільки-но завершилися вибори до ВР, як у Борисполі вже балакають про місиеві вибори у березні 2015 року. Чим ближче ия дата, тим напруга в суспільстві зростатиме. Усі хочуть показати, які вони найкращі депутати („Вісті”, 14.11.2014). Імовірно, використовуючи лексему балакають, автор висловлює думку, що майбутні вибори до органів місцевого самоврядування навесні нинішнього року — це лише порожні розмови, до яких не слід ставитися серйозно.

Замість нейтральної лексеми говорити в публіцистичних текстах на суспільно-політичну тематику, що характеризують міжнародні відносини, уживають розмовне дієслово подейкувати: “розм. говорити, розповідати що-небудь

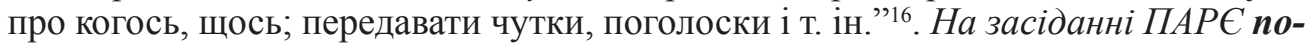
дейкують, щзо з Путіним щзось сталося („Високий замок”, 13.03.2015). Це слово використовують і в статтях про війну, порівн.: Подейкують, щзо воӥни протягом чотирьох діб вимагали виплати грошового забезпечення, зимової форми (,Час Київщини”, 17.10.2014). Актуалізуючи зазначену лексему, журналіст натякає, що інформація може бути недостовірною або ж такою, що обросла різноманітними чутками.

Серед дієслів мовлення журналісти використовують й ті, що репрезентують пласт зневажливої лексики. До прикладу, слово патякати відповідає нейтральному говорити і має кілька значень: “говорити багато про щось неістотне, пусте, не варте уваги; базікати, теревенити; вести довгу беззмістовну, непослідовну розмову; поширювати брехливі, небажані для кого-небудь або неправильні чутки"17, порівн.: У тій війні Україна зазнала найбільших втрат. По суті - зупинила ворога. Двічі із Заходу на Схід і в зворотному напрямку пройшли по нашій землі фронти. Зруйновані міста, спалені села... А тепер кремлівський фюрер не соромиться патякати, щзо й без Украӥни Росія перемогла б (,Чорноморські новини”, 7.05-9.05.2015); Я - однозначно за якнайшвидший вступ України до НАТО. Це - реальна гарантія нашої безпеки; я мобілізовуватиму громадськість задля иього... Треба діяти, а не патякати, а скиглитимемо „не візьмуть” - то так і буде, звичайно! (Д., 4.06.2015). Як бачимо, дієслово вжито в різних значеннях, однак воно має одне призначення - висловити зневагу автора до тих, про кого він пише, і наголосити на негативному ставленні до них.

Ще одна група дієслів, активно вживана в публіцистичних текстах під час опису стосунків України і Росії, — це дієслова руху і переміщення. О. Митрофанова пере-

\footnotetext{
${ }^{14}$ Там само, 1977, т. 8 , с. 301.

15 Там само, 1970, т. 1, с. 94.

${ }^{16}$ Словник украӥнської мови ..., 1975, т. 6, с. 738.

17 Там само, 1975, т. 6, с. 99.
} 
конана, що „лексико-семантична група дієслів руху виокремлюється з класу дієслів на основі інваріантної лексико-семантичної ознаки „зміна місцезнаходження в просторі”, а також абстрактних категоріальних ознак — „характер руху”, „спосіб переміщення”, „,ередовище переміщення”, „спрямованість переміщення” тощо”18.

Одне з таких дієслів містить лексико-семантичної ознаки „характер руху” punaтися: "розм., пориватися, намагатися кудись піти або зробити що-небудь"19, порівн.: Варіант прописатися в друзів, знайомих простий тільки на периий погляд - кримська прописка, а з нею й нерухомість на півострові буде втрачена. Висновок - сидіть $і$ не рипайтеся у своєму Криму (ДТ, 7.11.2014). Тут вербалізовано зневажливе ставлення до людей, які мешкають у тимчасово окупованому Криму, допустили від’єднання півострова від України, що призвело до безлічі проблем.

До дієслів руху та переміщення відносимо лексему вигулькувати: “розм., раптово, швидко з'являтися звідки-небудь, з-за чогось; показуватися, виглядати"20, що теж ужита в текстах про стосунки України та Росії, порівн.: Потім, вигулькнула новина, щуо буцімто деякі міжнародні спостерігачі [на Сході України] працүюють на Росію (Час Київщини, 14.11.2014). Це дієслово використовують і для характеристики представників влади, порівн.: Власне, ніхто, особливо не здивується, якщзо захисники екс-ректора таки "наврочать", i за короткий проміжок часу їхній підопічний вигулькне у лавах тієї чи іншої розкрученої політичної сили (УМ, 20.11.2014). Уживана лексема надає тексту іронічного відтінку. Автори глузують з тих, про кого пишуть.

3-поміж дієслів руху й переміщення виділимо лексему шастати: “розм., швидко, квапливо ходити, рухатися в різних напрямках (про людину, тварину)" 21 , порівн.: Просто так найвищі особи держав по ночах із заміських резиденцій до Кремля не шастають. А значить, сталося щзось справді серйозне (УМ, 5.12.2014). Це стилістично знижене дієслово створює експресивний ефект, що показує ставлення автора до можновладців, які іншої реакції, окрім осуду, неприязні та зневаги, не викликають.

Дієслова 3 семантикою руху та переміщення також активно використовують у статтях вітчизняної періодики на військову тематику. Серед них лексема возитися: “розм., займатися якоюсь клопітною справою; вовтузитися з ким або чим; повільно й довго робити щось, займатися ким-, чим-небудь"22, порівн.: ... часом ніхто не хоче особливо „возитися”, тим паче коли обсяги гуманітарної допомоги невеликі (Віче, 09.2014). Зі значенням „розм., проникати всередину чого-небудь, залізати кудись" 23 ужито слово пхатися, порівн.: Там, цивільних дуже багато поранених від обстрілу, то хто їм допоможе, на медиків, ні міліuіiі, нікого немає, ніхто близько й не пхається („Українське слово”, 4.11.2014).

Під час використання стилістично знижених дієслів возитися та пхатися журналісти показують ставлення до війни, що ніяк не закінчується, хоча солдати готові iii припинити, а населення не залишає ентузіазму допомагати захисникам. Дієслова стану та процесу орієнтовані на „пасивний” суб’єкт, реалізуються в тому відрізку часу, $з$ яким співвіднесені, отже, указують на тимчасову ознаку предмета ${ }^{24}$.

${ }^{18}$ О. Г. Митрофанова, Семантико-синтаксична структура речень із дієслівними предикатами руху і переміщення, Автореф. дис. канд. філол. наук, Запоріжжя 2007, с. 79.

${ }^{19}$ Словник украӥнської мови: ... 1977, т. 8, с. 537.

${ }^{20}$ Там само, 1970, т. 1, с. 381 .

${ }^{21}$ Там само, 1980, т. 11, с. 419.

${ }^{22}$ Словник української мови ... 1970, т. 1, с. 724.

${ }^{23}$ Там само, 1977, т. 8, с. 413.

${ }^{24}$ I. М. Кульчицький, М. О Лукач, Оәляд підходів до семантичної класифікаиії..., с. 112. 
Широко вживаним у публіцистичних текстах поч. XXI ст. є дієслово психічного стану оговтуватися: "розм., призвичаюватися до кого-, чого-небудь; освоюватися; повертатися до нормального стану; врівноважуватися" 25 . Його зустрічаємо в текстах української періодики, у яких описують ускладнені останнім часом стосунки України та Росії, зокрема характеризують політичних лідерів сусідньої держави, порівн.: Сталін не вірив у те, щзо Гітлер нападе. Чи навіть так: у момент, коли гітлерівські війська вже завдавали масштабних ударів по території СРСР та швидко просувалися вглиб країни, він не вірив, щзо изе відбувається. Вже відбувається: з ним, із територіями, з розбитою армією. Історики кажуть, щчо він оговтався за кілька днів (Т., 13.11.2014). Сам Путін дістав нокаутуючого удару від лідерів держав світової ичивілізаційної спільноти, від якого так і не зміг оговтатися („Голос України”, 18.11.2014). У наведеному тексті замість дієслова оговтатися можна було б використати більш нейтральне освоїтися, але тоді втратився би зміст самої думки, адже за допомогою розмовної лексеми автор натякнув читачам, що події, які він описує, вразили свого часу Сталіна і Путіна, які тривалий час призвичаювалися до нових обставин. Дієслово оговтуватися також уживають у текстах, де йдеться про вибори, порівн.: Щоб оговтатися від усієї изієї вакханалії, потрібен не день, а хоча б тиждень тиші. Інколи телеканали, відволікаючись від виборів, усе-таки згадували, щзо країна щее й воює (Д., 31.10.2014). Притаманне дієслово і публікаціям, у яких автор розкриває соціальні питання: ...один із роботодавців таки погодився у Вишгородському районі надати приміщзення для ГО „Заробітчани”, де приїжджі неофіти могли б оговтуватися серед свойх на новому місці (УМ, 03.02.2015). Актуалізована лексема сприяє підсиленню емоційного та психічного стану автора чи тих, про кого він пише.

Дієслова дії позначають діяльність, що породжена особою та активно й безпосередньо нею стимулюється. До цієї групи відносимо лексему напинати: “розм., надягти, накладати на себе який-небудь одяг"26, у процесі застосування якої автори моделюють у тексті смисл зневаги до тих, хто показово демонструє любов до Батьківщини, порівн.: Усі в нас щирі украӥнці і не втрачають нагоди нап'ясти на себе вишиванку. Це ж яке сталеве сумління треба мати, щуб бачити / слухати / читати про численні смерті людей.., і паралельно складати прейскурант власних незаконних послуг („Галицьке слово”, 19.06.2015). Так засуджують зрадників України, які дбають лише про своє благополуччя, обкрадаючи народ.

Отже, у мові періодики поч. XXI ст. спостерігаємо активне вживання лексики розмовного стилю, зокрема дієслів різних лексико-семантичних груп. Їх найчастіше використовують у текстах суспільно-політичного змісту. Найпоширенішими є дієслова мовлення, які за значенням можна об'єднати семемою говорити. Як лексеми, що репрезентують належність до розмовного стилю мовлення, вони виконують функцію увиразнення негативної думки переважно про політиків-корупціонерів, зрадників, ворогів чи акцентують увагу на зневажливому та осудливому ставленні до них. Крім розмовних одиниць, які є синонімами до слова говорити, зустрічаємо лексеми, що в словниках позначені ремаркою ,зневажливе”.

Окрім дієслів мовлення, на сторінках вітчизняної періодики простежуємо активне функціонування й дієслів руху і переміщення, стану і процесу та дії, що теж використані для осуду і критики.

\footnotetext{
${ }^{25}$ Словник украӥнської мови ... 1974, т. 5, с. 618.

${ }^{26}$ Там само, 1974 , т. 5, с. 142.
} 